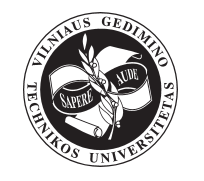

\title{
ASSESSING EXTERNAL THREATS TO STRUCTURES USING LIMITED STATISTICAL DATA: AN APPROACH BASED ON DATA RESAMPLING
}

\author{
Egidijus R. Vaidogas and Virmantas Juocevičius \\ Dept of Reinforced Concrete and Masonry Structures, Vilnius Gediminas Technical University, \\ Sauletekio al. 11, LT- 10223 Vilnius, Lithuania
}

Received 23 January 2007; accepted 7 June 2007

\begin{abstract}
The paper deals with an estimation of risk to structures posed by extreme, dangerous phenomena called in brief the external threats. It is considered how to calculate risk values when a limited amount of data on actions imposed by these phenomena is available. The key methodology suggested in the paper for estimating the risk is the so-called bootstrap resampling, known also as statistical or Efron's resampling. The paper presents a procedure allowing to apply the limited data to calculating bootstrap confidence intervals for probabilities of damage which can be caused by the actions. The application of the procedure is based on the assumption that the limited data can be expressed in the form of statistical sample which possesses the property of representativeness. It is discussed how to incorporate the confidence intervals in an expression of the risk induced by external threats. The proposed procedure can be viewed as a way of utilising limited and often very expensive data gained from experiments imitating occurrences of external threats. Findings described in this paper can be applied to design the structures for the so-called accidental situations.
\end{abstract}

Keywords: threat, accidental action, damage, fragility function, uncertainty, bootstrap confidence interval.

\section{Introduction}

External threats (ETs) to structures (structural systems) are posed by natural and man-made physical phenomena occurring generally as rare, short lasting events and imposing dangerous actions on exposed structures. These actions can damage the structures, and, according to the action classification used in the structural engineering, they should be called the accidental or abnormal ones [1-3].

It is reasonable to suppose that an ET can be assessed by the character and magnitude of possible damage it can cause to an exposed structure. A natural and fairly comprehensive measure of this threat is the risk expressed in the form presently accepted in the field of quantitative risk assessment (QRA) (eg [4, 5]). In line with this form, the risk posed by the ET to an exposed structure can be represented as a set of pairs "damage event"-“frequency of damage event" [6]. With the risk as measure of ET, assessing this threat will amount to (i) identification of possible damage events, which may take place in case of occurrence of the threat; and (ii) estimation of the frequencies of these damage events.

As far as the risk to exposed structures is concerned, each ET can be classified according to the nature and amount of information on the actions which can cause damage during an occurrence of the threat. A need to calculate this risk will put the engineer (team of analysts) most probably in one of the following situations: in the first situation it may be possible to predict the actions and so the damage by more or less accurate mathematical models of the physical phenomena behind ET; some statistical data may back these models and allow estimating their parameters; in the second situation, on the contrary, a limited amount of direct statistical data on the actions may be available in the form of experimental or in-the-field measurements or indirect values gained from post-mortem examinations of similar accidents (back experiments). The situations of zero-knowledge about possible actions or, alternatively, presence of large amounts of direct statistical data on the action values are less probable.

This paper deals with assessing ETs in the second situation, that is, the situation of limited direct data. The word "limited" means that the amount of data is too small to apply automatically procedures of the classical statistics to fitting probabilistic models of possible actions, which then could be used for estimating frequencies of damage events. It is suggested that inferences about these frequencies can be drawn using a statistical resampling method referred to as bootstrap. The central idea is to estimate the frequencies by calculating bootstrap confidence intervals (BCIs) for probabilities of the damage events using an artificial sample consisting of estimates of these probabilities and obtained by means of a structural reliability analysis (SRA). 


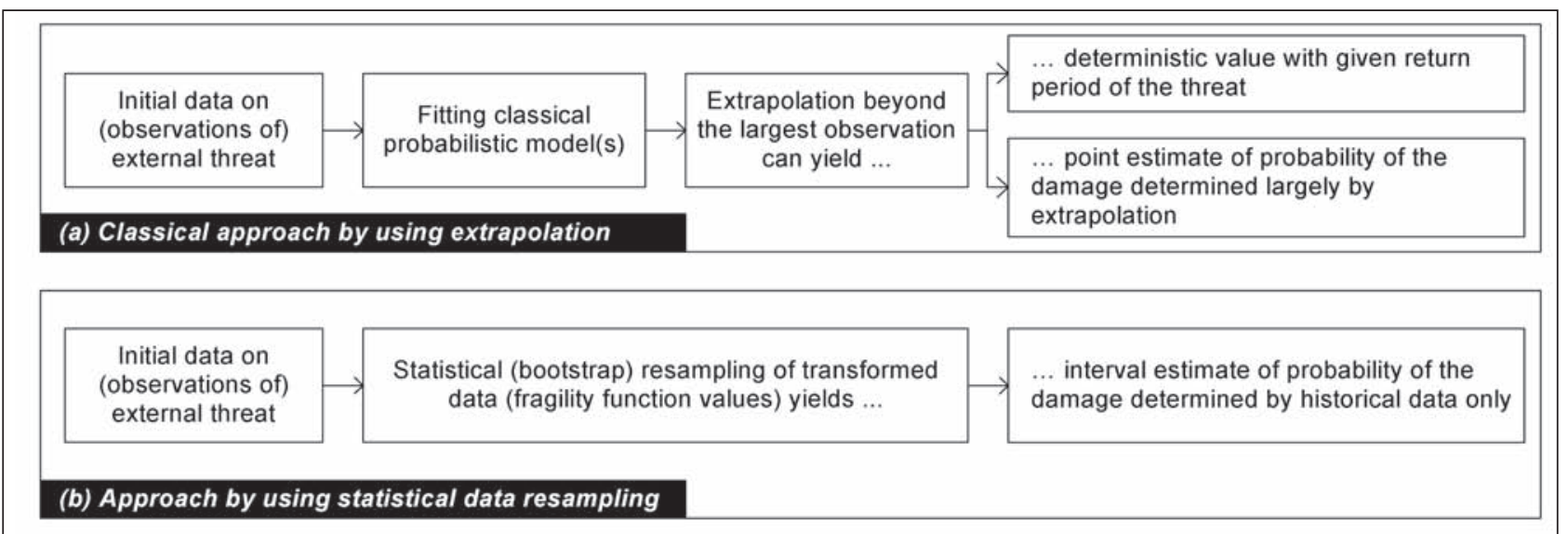

Fig 1. Two basic approaches to handling scarce data on external threat

\section{Mathematical framework and problem addressed}

The risk used to measure an ET to a structure may be defined in the form

$$
\text { Risk } \equiv\left\{\left(F_{i}, D_{i}\right), i=1,2, \ldots, n_{d}\right\},
$$

where $D_{i}$ - the random event of the $i$ th damage to structure due to the ET; $F_{i}$ - the frequency of suffering this damage measured, say, in 1/year; and $n_{d}$ - the number of foreseeable damage events. The above definition of risk embraces only the adverse events of structural nature, $D_{i}$, should of course be considered a part or a simplified version of the general risk posed by the ET. The general risk, on the other hand, can hardly be calculated without estimating frequencies $F_{i}$ of the damage events $D_{i}$, which can determine to a large degree non-structural consequences of the ETs.

The frequency $F_{i}$ may be expressed as the product

$$
F_{i}=F(O E T) P\left(D_{i} \mid O E T\right),
$$

where $F(O E T)$ - the frequency of the event "occurrence of an ET" $(O E T)$; and $P\left(D_{i} \mid O E T\right)$ - the conditional probability of $D_{i}$ given $O E T$. This conditional probability can be expressed as

$$
P\left(D_{i} \mid O E T\right)=\int_{\text {all } x} P\left(D_{i} \mid \boldsymbol{x}\right) \mathrm{d} F_{\boldsymbol{X}}(\boldsymbol{x})=E\left(P\left(D_{i} \mid \boldsymbol{X}\right)\right),
$$

where $\boldsymbol{X}$ - the random vector of characteristics of the physical phenomenon behind the ET; $\boldsymbol{x}$ - the value of $\boldsymbol{X}$; and $F_{X}(\boldsymbol{x})$ - the distribution function (d.f.) of $\boldsymbol{X} ; P\left(D_{i} \mid \boldsymbol{x}\right)$ - the fragility function quantifying the probability of $D_{i}$ given $O E T$ with the characteristics $\boldsymbol{x}$. The symbol $E($.$) in the above$ expression denotes a mean value.

The last two expressions split the problem of estimating the frequency $F_{i}$ into estimating $F(O E T)$, developing the fragility function $P\left(D_{i} \mid \boldsymbol{x}\right)$, and fitting $F_{\boldsymbol{X}}(\boldsymbol{x})$. Obtaining estimates of $P\left(D_{i} \mid \boldsymbol{x}\right)$ denoted in what follows by $p_{e}$ is almost purely a problem of SRA, which of course cannot be solved without having d.f. $F_{X}(\boldsymbol{x})$. Given $F_{X}(\boldsymbol{x})$, the estimation of $P\left(D_{i} \mid O E T\right)$ amounts to a relatively simple computation of the mean value $E\left(P\left(D_{i} \mid \boldsymbol{X}\right)\right)$.

\section{Possibilities to apply statistical resampling}

In case of rare threats, which can cause damage events $D_{i}$ imposing severe consequences of both structural and nonstructural nature, a sample of action values, $\mathbf{x}=\left(\boldsymbol{x}_{1}, \boldsymbol{x}_{2}, \ldots\right.$, $\left.\boldsymbol{x}_{n}\right)^{T}$, may be available from post-mortem examinations of accidents occurring as a particular ET or from experimentations with (in-the-field observations of) the physical phenomenon constituting the ET. More often than not the sample size $n$ will be such that an application of the classical statistical methods to fitting $F_{X}(\boldsymbol{x})$ will be hardly possible. Thus it will be difficult, if not impossible, to keep the usual track of data processing shown in Fig 1a.

So long as a QRA measure, namely, the risk is used for assessing the ETs, it stands to reason to apply QRA methods to a choice of the action model $F_{X}(\boldsymbol{x})$ and eventually to an estimation of the damage frequencies $F_{i}$. State-of-theart methods of QRA are based on the Bayesian statistical theory and are called Bayesian approaches to risk assessment (see eg [7]). These approaches fit fairly well methodological demands of QRA; however, their application to assessing ETs to structures may be hampered by two stumbling blocks of a practical nature:

- Firstly, the "Bayesian" situation, when the experience in the form of the sample elements $\boldsymbol{x}_{n+1}, \boldsymbol{x}_{n+2}, \ldots$ arrives a little bit at a time and allows gradual updating the action model $F_{X}(\boldsymbol{x})$, is not typical of many ETs;

- Secondly, the subjectivity of the action model $F_{X}(x)$ and frequencies $F_{i}$ quantified using the Bayesian approaches may be unacceptable to decision-makers in the traditional field of structural engineering. Many of them are not especially friendly neither to SRA nor to QRA and can simply require to assess the threats only on the basis of "objective" information available in the form of the sample $\mathbf{x}$.

An equivalent alternative to the Bayesian approaches can hardly be found; however, the stumbling blocks could be in some senses side-stepped by applying statistical resampling to the estimation of the damage probabilities $P\left(D_{i} \mid\right.$ OET $)$. In particular, bootstrap methods could be used for doing statistical inferences in the situation of limited data represented by the sample $\mathbf{x}$. Bootstrap is a set of data- 


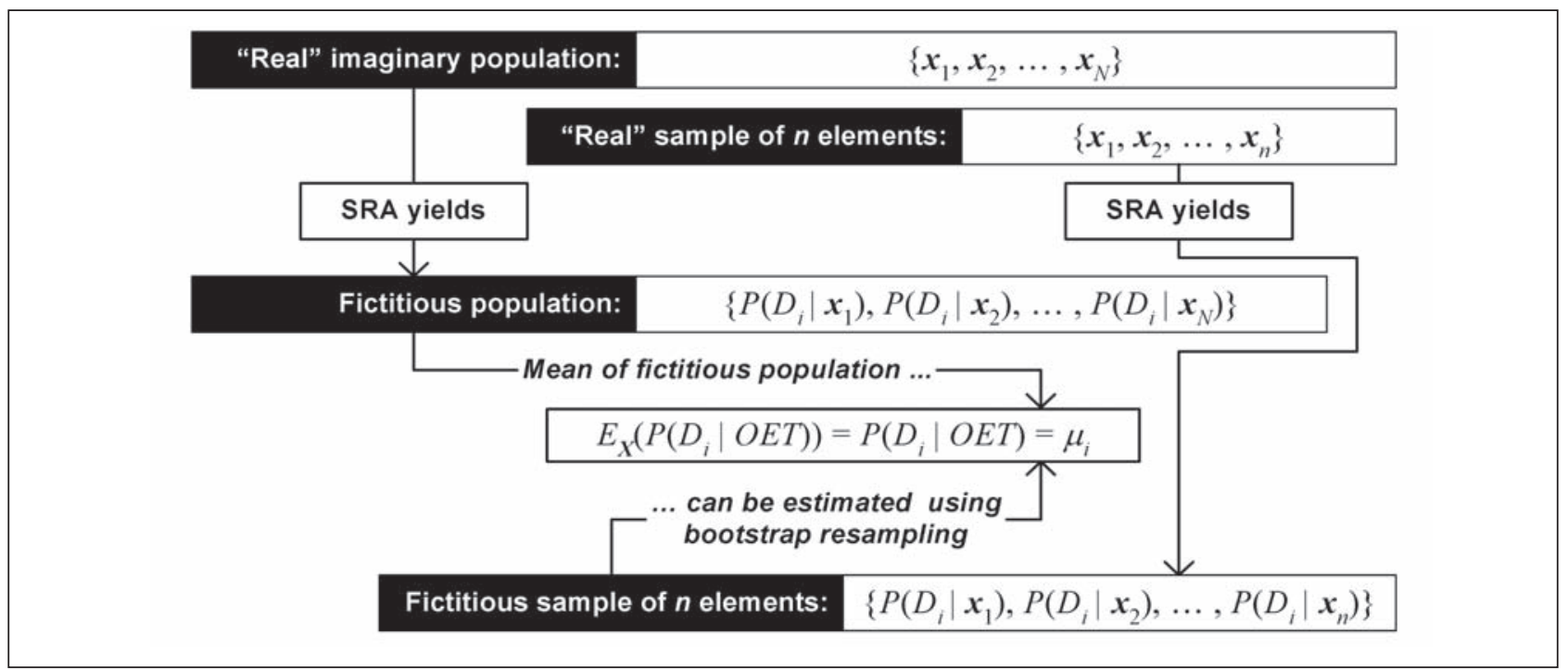

Fig 2. Damage probability estimation by means of statistical resampling (bootstrap resampling)

based simulation methods for statistical inference without analytical calculation $[8,9]$. These methods can be applied in a completely automatic way. As applied to predicting damage from external threats, bootstrap methods can serve for an interval estimation of damage probabilities $P\left(D_{i} \mid O E T\right)$ (Fig 1a).

A conventional application of bootstrap may be limited to the level of mathematical modelling actions imposed by an ET and start from drawing some number $B$ of bootstrap samples $\mathbf{x}_{1}^{\prime}, \mathbf{x}_{2}^{\prime}, \ldots, \mathbf{x}_{B}^{\prime}$ from the original sample $\mathbf{x}$ or its empirical distribution.

The bootstrap samples can be applied to constructing confidence intervals for percentiles of components of $\boldsymbol{X}[10]$. These intervals may be of interest to a deterministic damage prediction. Bootstrap provides also means for a resampling-based estimation of probability density of $\boldsymbol{X}$ [11]. To the best of author's knowledge there are some theoretical problems and difficulties of practical implementation of the bootstrap density estimation at small sample size $n$ and relatively large dimensionality of $\boldsymbol{X}$. These difficulties can be bypassed by switching the level at which the statistical inference is to be done in order to estimate the damage probabilities $P\left(D_{i} \mid O E T\right)$.

Instead of an indirect estimation of $P\left(D_{i} \mid\right.$ OET $)$ by drawing bootstrap-based statistical inferences about the action characteristics $\boldsymbol{X}$ from the sample $\mathbf{x}$ and a succeeding application of them to this estimation, one can create a onedimensional fictitious sample $\boldsymbol{p}=\left(p_{e 1}, p_{e 2}, \ldots, p_{e j}, \ldots, p_{e n}\right)^{\mathrm{T}}$ (Fig 2). Each element of this sample, $p_{e j}$, is an estimate of the corresponding fragility function value $P\left(D_{i} \mid \boldsymbol{x}_{j}\right)$. The sample element $p_{e j}$ can be applied, so to say, to draw directly bootstrap-based inferences about values of $P\left(D_{i} \mid\right.$ OET $)$. Clearly, the quality of these inferences will depend on the size of the bias $p_{e j}-P\left(D_{i} \mid \boldsymbol{x}_{j}\right)$ which should be kept as small as possible.

The bootstrap-based inferences about $P\left(D_{i} \mid\right.$ OET $)$ drawn using values $p_{e j}$ should be made in the form which allows to incorporate them into the expression of the damage fre- quency $F_{i}$ and thus the risk posed by the ET under consideration. A possible way to do this is to apply a simulation procedure for calculating BCIs of the damage probabilities $P\left(D_{i} \mid O E T\right)$.

\section{Proposed resampling procedure}

The definition of the damage probability $P\left(D_{i} \mid O E T\right)$ given in section 2 implies that estimating $P\left(D_{i} \mid O E T\right)$ can be realised as estimating a mean of a population with unknown probability distribution using a small sample $\boldsymbol{p}$. This means can be estimated by a BCI ] $P\left(D_{i} \mid O E T\right)$ $\bar{P}\left(D_{i} \mid O E T\right)[$, where the lower and upper strokes are used to denote lower limit and upper limit of the interval, respectively.

Bootstrap provides several methods for calculating confidence intervals for means, each of which starts from drawing $B$ bootstrap samples $\boldsymbol{p}_{1}^{\prime}, \boldsymbol{p}_{2}^{\prime}, \ldots, \boldsymbol{p}_{B}^{\prime}$ from the original sample $\boldsymbol{p}[8,9]$. The entire procedure of estimating $P\left(D_{i} \mid\right.$ OET $)$ by means of BCIs intervals is illustrated in Fig 3.

With the confidence interval for $P\left(D_{i} \mid O E T\right)$, one can construct a confidence interval for the damage frequency $F_{i}$, namely, by calculating the values

$$
\bar{F}_{i}=F_{e}(O E T) \times \bar{P}\left(D_{i} \mid O E T\right)
$$

and

$$
\underline{F}_{i}=F_{e}(O E T) \times \underline{P}\left(D_{i} \mid O E T\right),
$$

where $F_{e}(O E T)$ - an estimate of the frequency of $O E T$. With these values, the risk posed by an ET to a structure can be expressed in the form

$$
\text { Risk } \equiv\left\{(] \underline{F}_{i}, \bar{F}_{i}\left[, D_{i}\right), i=1,2, \ldots, n_{d}\right\} .
$$

The application of bootstrap does not allow avoiding completely a subjectivity of the risk. It is introduced by incorporating the confidence intervals in the expression of risk, because the engineer must make judgement regarding what 


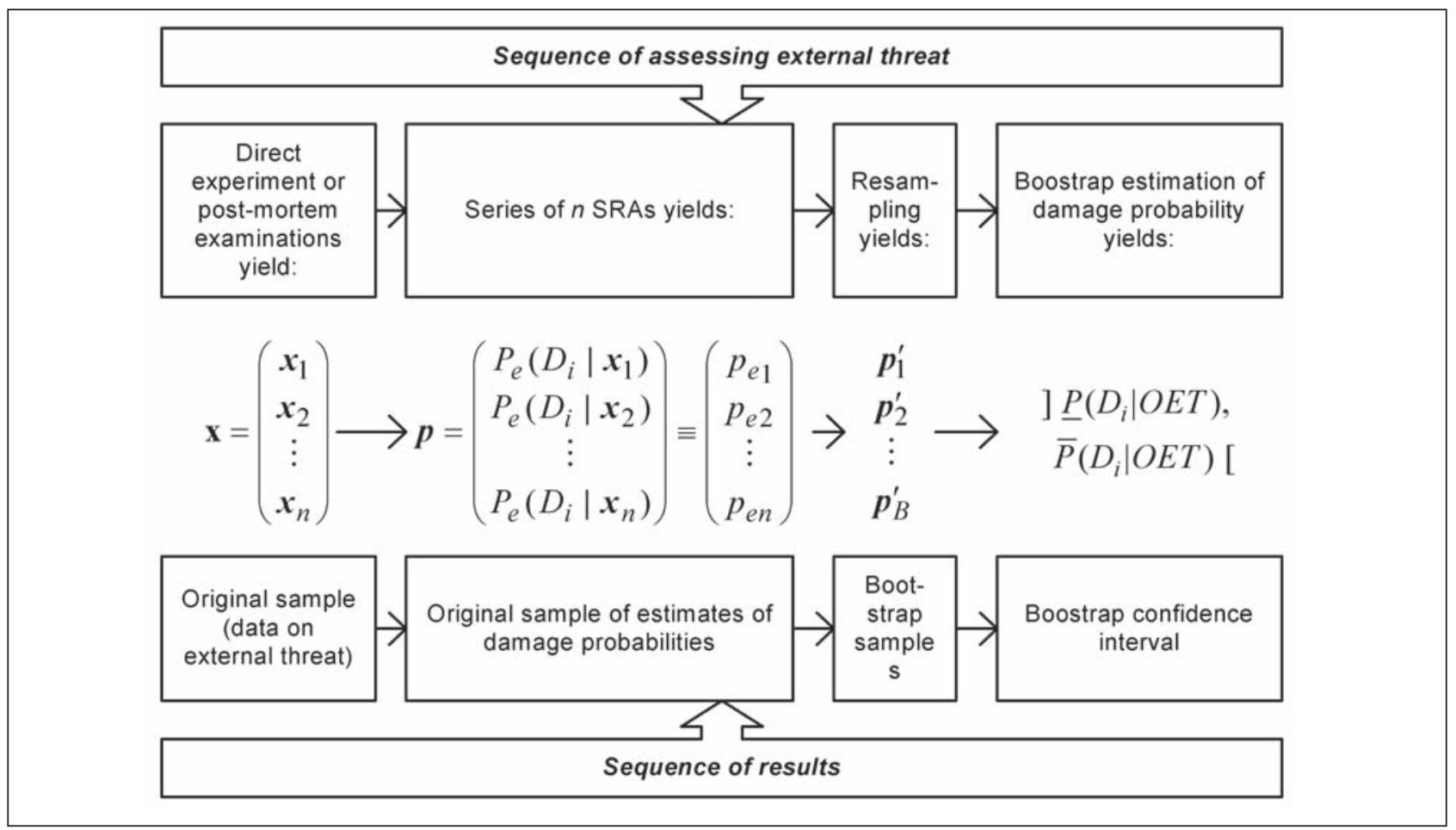

Fig 3. Resampling-based procedure for estimating probabilities of damage due to external threats to structures (SRA = structural reliability analysis)

degree of confidence to use for the intervals. It may also be necessary to judge subjectively, whether the data $\mathbf{x}$ is a relevant random representative sample, or whether a particular value $\boldsymbol{x}_{j}$ can be included in the sample $\mathbf{x}$.

\section{Example: explosive damage to external RC panel}

Consider a reinforced concrete (RC) wall panel exposed to an ET of a distant accidental explosion of hazardous equipment. A reflection of the shock wave generated by this explosion can cause flexural failure (damage event $D_{1}$ ) or shear failure (damage event $D_{2}$ ) of the panel. The table contains a sample consisting of 15 sets of incident shock wave characteristics, $\boldsymbol{x}_{i}$, and two samples of estimates of the damage probabilities $P\left(D_{1} \mid \boldsymbol{x}_{j}\right)$ and $P\left(D_{2} \mid \boldsymbol{x}_{j}\right)$, namely, $\boldsymbol{p}_{1}=\left(p_{1 e j} j=1,2, \ldots\right.$ , 15) and $\boldsymbol{p}_{2}=\left(p_{2 e j}, j=1,2, \ldots, 15\right)$. These samples were obtained using a SRA method proposed papers $[12,13]$.

The BCIs for $P\left(D_{1} \mid \boldsymbol{x}_{j}\right)$ and $P\left(D_{2} \mid \boldsymbol{x}_{j}\right)$ were calculated by generating $B=1000$ independent bootstrap samples $\boldsymbol{p}_{11}^{\prime}$, $\boldsymbol{p}_{12}^{\prime}, \ldots, \boldsymbol{p}_{1 B}^{\prime}$ and $\boldsymbol{p}_{21}^{\prime}, \boldsymbol{p}_{22}^{\prime}, \ldots, \boldsymbol{p}_{2 B}^{\prime}$ computing mean values of them, $\bar{p}_{1 b}^{\prime}$ and $\bar{p}_{2 b}^{\prime}, b=1,2, \ldots, B$. The confidence intervals were constructed by applying an approach based on percentiles of the samples of $\bar{p}_{1 b}^{\prime}$ and $\bar{p}_{2 b}^{\prime}$ [8]. The 0,95 confidence intervals were obtained as percentile intervals

$$
\mathrm{BCI}=] \bar{p}_{1 b, 0.025}^{\prime}, \bar{p}_{1 b, 0.975}^{\prime}[
$$

and

$$
\mathrm{BCI}=] \bar{p}_{2 b, 0.025}^{\prime}, \bar{p}_{2 b, 0.975}^{\prime}[.
$$

The samples $\mathrm{p} 1$ and $\mathrm{p} 2$ yield the intervals

$$
\mathrm{BCI}=] \underline{P}\left(D_{1} \mid O E T\right), \bar{P}\left(D_{1} \mid O E T\right)[=] 0,125 ; 0,134[
$$

\begin{tabular}{|c|c|c|c|c|c|c|c|c|}
\hline$j$ & 1 & 2 & 3 & 4 & 5 & 6 & 7 & 8 \\
\hline $\mathbf{x}_{j}=\left(x_{1 j}, x_{2 j}, x_{3 j}\right)^{\mathrm{T}}$ & $\begin{array}{l}0,052 \\
13 \\
73\end{array}$ & $\begin{array}{l}0,071 \\
19 \\
82 \\
\end{array}$ & $\begin{array}{l}0,094 \\
28 \\
72\end{array}$ & $\begin{array}{l}0,047 \\
11 \\
85\end{array}$ & $\begin{array}{l}0,064 \\
17 \\
68\end{array}$ & $\begin{array}{l}0,087 \\
23 \\
53\end{array}$ & $\begin{array}{l}0,051 \\
14 \\
77\end{array}$ & $\begin{array}{l}0,043 \\
10 \\
82\end{array}$ \\
\hline $\begin{array}{l}p_{1 e j} \\
p_{2 e j}\end{array}$ & $\begin{array}{l}0,121 \\
0,0741 \\
\end{array}$ & $\begin{array}{l}0,134 \\
0,0825 \\
\end{array}$ & $\begin{array}{l}0,157 \\
0,0964 \\
\end{array}$ & $\begin{array}{l}0,118 \\
0,0740 \\
\end{array}$ & $\begin{array}{l}0,132 \\
0,0818\end{array}$ & $\begin{array}{l}0,137 \\
0,0843 \\
\end{array}$ & $\begin{array}{l}0,122 \\
0,0749\end{array}$ & $\begin{array}{l}0,113 \\
0,0695 \\
\end{array}$ \\
\hline$j$ & 9 & 10 & 11 & 12 & 13 & 14 & 15 & \\
\hline $\mathbf{x}_{j}=\left(x_{1 j}, x_{2 j}, x_{3 j}\right)^{\mathrm{T}}$ & $\begin{array}{l}0,067 \\
17 \\
51\end{array}$ & $\begin{array}{l}0,054 \\
12 \\
48\end{array}$ & $\begin{array}{l}0,078 \\
22 \\
63\end{array}$ & $\begin{array}{l}0,077 \\
25 \\
66\end{array}$ & $\begin{array}{l}0,085 \\
27 \\
74\end{array}$ & $\begin{array}{l}0,081 \\
24 \\
69\end{array}$ & $\begin{array}{l}0,072 \\
20 \\
49\end{array}$ & \\
\hline $\begin{array}{l}p_{1 e j} \\
p_{2 e j}\end{array}$ & $\begin{array}{l}0,128 \\
0,0786 \\
\end{array}$ & $\begin{array}{l}0,114 \\
0,0700 \\
\end{array}$ & $\begin{array}{l}0,133 \\
0,0798 \\
\end{array}$ & $\begin{array}{l}0,132 \\
0,0811 \\
\end{array}$ & $\begin{array}{l}0,136 \\
0,0837 \\
\end{array}$ & $\begin{array}{l}0,141 \\
0,0867\end{array}$ & $\begin{array}{l}0,121 \\
0,0743\end{array}$ & \\
\hline
\end{tabular}

Samples of characteristics of incident shock wave, $\boldsymbol{x}_{j}$, and estimates of probability of flexural and shear failure of the wall panel, $p_{1 e j}$ and $p_{2 e j}$, corresponding to $\boldsymbol{x}_{j} \mathrm{~s}^{1)}$ 
and

$$
\mathrm{BCI}=] \underline{P}\left(D_{2} \mid O E T\right), \bar{P}\left(D_{2} \mid O E T\right)[=] 0,0761 ; 0,0831[
$$

One can see that in case of the damage event $D_{1}$ the confidence interval covers $0,9 \%$ of the interval of possible probability values, whereas the interval related to $D_{2}$ is narrower and its width can be expressed as $0,9 \%$ of the above interval. Clearly, this precision could be less impressive, be the variance of the samples $\boldsymbol{p}_{1}$ and $\boldsymbol{p}_{2}$ larger and the fragility functions $P\left(D_{1} \mid \boldsymbol{x}_{j}\right)$ and $P\left(D_{2} \mid \boldsymbol{x}_{j}\right)$ less steep.

\section{Conclusions}

The present paper was devoted to assessing risk to structures due to the phenomena external with respect to structures and can damage them. In brief, these phenomena were called the external threats (ETs). It was shown that an ET can be assessed by calculating risk expressed as a set of pairs "damage event"-"frequency of damage event". If some limited statistical data on potential actions, which may be imposed by the ET, is available, it is possible to estimate the frequency of each foreseeable damage event by applying a statistical resampling method known as bootstrap. This method was applied to calculating confidence intervals for probabilities of each damage event. It was shown that these can be transformed into confidence intervals of damage frequencies. Bootstrap-based confidence intervals were calculated for a sample of estimates of damage probabilities. These estimates can be obtained from a historical data on values of actions induced by the ET using methods of a structural reliability analysis.

The proposed procedure of the resampling-based estimation of the damage probabilities can be applied for design of structures for the accidental design situations. The key element of such a situation is accidental (abnormal) action(s) which, in many cases, can be interpreted as external threat. Occurrences of accidental actions are rare and difficult-to-predict events. Information on characteristics of accidental actions will usually be limited. In some cases this information will not be available at all. Then a prediction of damage due to an accidental action can be based on a series of repeated experiments. They can yield a representative statistical sample in case that the experiments are arranged by following principles of statistical sampling.

The resampling-based estimation of damage probabilities can be applied also for assessing the risk to structures in context of a general risk analysis of critical and hazardous facilities run in different industries. However, the proposed procedure is based on classical (Fisherian) statistical inference and so is fully applicable to structural reliability analysis. The latter methodology, as a well-known, rests primarily on this type of statistical analysis. Thus the proposed procedure fits naturally in the reliability-based analysis and design of structures.

\section{References}

1. ISO 2394: General principles on reliability for structures. ISO, Geneve, 1998. $92 \mathrm{p}$.

2. ELLINGWOOD, B. R. and DUSENBERRY, D. O. Building design for abnormal loads and progressive collapse. Computer-Aided Civil and Infrastructure Engineering, 2005, Vol 20, p. 194-205.

3. GRIERSON, D. E., XU, L. and LIU, Y. Progressive-failure analysis of buildings subjected to abnormal loading. Computer-Aided Civil and Infrastructure Engineering, 2005, Vol 20, p. $155-171$.

4. KUMAMOTO, H.; HENLEY, E. J. Probabilistic risk assessment for engineers and scientists. 2nd ed. IEEE Press, New York, 1996. $597 \mathrm{p}$

5. AYYUB, B. M. Risk Analysis in Engineering and Economics. Chapman \& Hall/CRC, Boca Raton etc., 2003. 571 p.

6. VAIDOGAS, E. R. Accidental explosions: Bayesian uncertainty handling in assessing damage to structures. In Proc of ICASP9, Millpress, Rotterdam, 2003, p. 191-198.

7. NILSEN, T.; AVEN, T. Models and model uncertainty in the context of risk analysis. Reliability Engineering and System Safety, 2003, Vol 79, p. 309-317.

8. EFRON, B.; TIBSHIRANI, R. J. An Introduction to the bootstrap. Chapman \& Hall, New York, 1998. 436 p.

9. DAVISON, A. C.; HINKLEY, D. V. Bootstrap methods and their application. Cambridge: Cambridge University Press, 1998. $583 \mathrm{p}$.

10. Leblanc, M. Resampled quantile functions for error estimation and a relationship to density estimation. Computational Statistics \& Data Analysis, 1999, Vol 29, p. 163-176.

11. LÉGER, M. et al. Bootstrap technology and applications. Technometrics, 1992, Vol 34, p. 378-398.

12. LOW, H. Y.; HAO, H. Reliability of direct shear and flexural failure modes of RC slabs under explosive loading. Engineering Structures, 2002, Vol 24, p. 189-198.

13. VAIDOGAS, E. R. Explosive damage to industrial buildings: assessment by resampling experimental data on blast loading. Journal of Civil Engineering and Management, 2005, Vol XI, No 4, p. 251-266.

\section{IŠORINIŲ PAVOJŲ STATYBINĖMS KONSTRUKCIJOMS VERTINIMAS ATLIEKANT KARTOTINİ STATISTINI DUOMENŲ ĖMIMĄ APIE ŠIUOS PAVOJUS}

\section{E. R. Vaidogas, V. Juocevičius}

Santrauka

Straipsnyje nagrinėjama, kaip vertinti konstrukcijų pažeidimų riziką, sukeliamą ekstremalių ir pavojingujų reiškinių, pavadintų išoriniais pavojais. Parodyta, kaip skaičiuoti rizikos reikšmes, kaip turima ribota statistinė infomacija apie poveikius, sukeliamus pavojinguju reiškinių. Straipsnyje pasiūlyta procedūra, leidžianti išnaudoti šią informaciją rizikos įverčiams skaičiuoti. Procedūros esmę sudaro kartotinis statistinis duomenų apie pavojingujų reiškinių sukeliamus poveikius ėmimas, atliekamas plètros (angl. bootstrap) 
metodu. Ši procedūra leidžia skaičiuoti pasikliautinuosius konstrukcijos pažeidimų tikimybių intervalus. Parodyta, kad juos nesunku transformuoti i pasikliautinuosius pažeidimų dažnių intervalus. Juos galima taikyti formuojant kiekybinę konstrukcijos pažeidimų rizikos išraišką.

Reikšminiai žodžiai: pavojus, avarinis poveikis, pažaida, pažeidžiamumo funkcija, neapibrèžtumas, kartotinis ėmimas, pasikliautinasis intervalas.

Egidijus Rytas VAIDOGAS. Professor of the Dept of Reinforced Concrete and Masonry Structures at VGTU. Representative of the Republic of Lithuania in the European technological platform on industrial safety. Research interests: reliability of structures, risk analysis and management, safety of technological and technical systems.

Virmantas JUOCEVIČIUS. Post-graduate student of Dept of Reinforced Concrete and Masonry Structures at VGTU. 